\title{
SOIL AMELIORANTS TO IMPROVE SOIL CHEMICAL AND MICROBIAL BIOMASS PROPERTIES IN SOME SOUTH AFRICAN SOILS
}

\author{
T. C. Baloyi ${ }^{1}$, C. C. Du Preez ${ }^{2}$ and F. R. Kutu ${ }^{3}$
}

\begin{abstract}
Rainfed field trials on effects of seed, foliar and soil amendments herein referred as industrially manufactured biological amendments (IMBAs) on selected soil chemical and microbial biomass properties were conducted from 2006/07through 2008/09 at four sites in South Africa under light and heavy-textured soils. The IMBAs were classified as growth boosters and partial or total replacements of conventional NPK fertiliser. The IMBAs were applied according to product recommendations in a randomised complete block design with four replications. An optimum conventional NPK rate at each site and untreated control were also included as check. Application of IMBAs with optimum recommended NPK fertiliser rate promoted acidity in soils compared to the IMBAs used as either partial or total replacements of conventional NPK fertiliser. The use of the different IMBA types significantly increased contents of organic $C$, available $N$ and $P$ only in light-textured soils than in the NPK check. The different IMBAs promoted higher microbial biomass-C immobilisation at 4-weeks after planting, while biomass-C mineralisation was predominant at flowering and crop harvest regardless of soil type. Farmers could apply any category of IMBAs to complement revitalisation of degraded South African soils and also minimise nutrient leaching due to synergetic effects.
\end{abstract}

Keywords: Conventional fertiliser, fertiliser replacement, growth booster, soil productivity

\section{INTRODUCTION}

Soils in the maize producing triangle of South Africa are sandy and light-textured and hence highly subjected to occasional nutrient leaching rendering them deficient in major plant nutrients (Laker, 1976; Mills and Fey, 2003). These soils are often associated with restricted factors such as compaction, acidity and low organic carbon stocks (Mnkeni and Mkile, 2006). This consequence in crop production to be practiced on biologically inactive and physically deteriorated soils that results in crops responding less to the use of chemical inputs (Primavesi, 1990).

The sole use of conventional NPK fertilisers to meet soil nutrient requirements often increases the rate of organic matter $(\mathrm{OM})$ mineralisation and leads to a decrease in easily decomposable $\mathrm{OM}$ as well as a decrease in microbial biomass (Černý et al., 2003). Prolonged application of nitrogenous fertilisers may also lead to problems of soil acidity and nutrient imbalance (Gilani and Bahmanyar, 2008). However, sole application of organic amendments increases soil microbial biomass carbon, while no increase and/or effect resulted with inorganic NPK fertilisers (Goshal and Singh, 1995). Microbial biomass and activity directly correlate with OM, which is positively influenced by the addition of organic materials such as post-harvest crop residues and manure (Belay et al., 2002). Hence, microorganism activities in agricultural soils exert a profound influence on plant nutrient availability and OM transformation (Onwonga et al., 2010).

The need to reduce crop fertilising costs is important grounds for advocating increased use of organic amendments. Benefits arising from the use of organic materials are not

2 Department of Soil, Crop and Climate Sciences, University of the Free State, P.O. Box 339, Bloemfontein 9300, South Africa.

3 School of Agriculture and Environmental Sciences, University of Limpopo, Turfloop Campus, P/Bag X1106, Sovenga 0727, South Africa. 
fully exploited partly due to huge quantities required in order to satisfy the nutritional needs of crops (Hossain and Singh, 2000). Complementary use of organic manures and inorganic fertilisers has proven to be a sound soil fertility management strategy in many countries of the world (Heisey and Mwangi, 1996). In South Africa, there are many organic-based fertilisers manufactured and marketed for agriculture that advocate soil health revitalisation properties, but often without sufficient empirical information on efficacy or possible soil impacts. Limited studies report significant benefits following the use of organically-enriched amendments as alternatives or in combination with conventional NPK fertiliser (Baloyi et al., 2010; Kutu, 2012). These authors emphasise the possible benefits of the use of plant/soil ameliorants to improve crop growth, but only on selected soil quality indices. This study was therefore conducted to assess effects of seed, foliar and soil amendments on growth of maize and soil properties. Nonetheless, only the responses of selected soil chemical and microbial biomass properties to usage of industrially manufactured biological amendments (IMBAs) are primarily addressed in this paper.

\section{MATERIALS AND METHODS}

\section{Site characterisation}

Field trials with maize variety PAN 6479 were conducted under rainfed conditions over three cropping seasons during 2006/07 to $2008 / 09$ at four localities. The three sites namely, Bethlehem, Bothaville and Ottosdal represented light-textured soils, while the fourth site at Potchefstroom represented heavy-textured soils (Table 01). Climatic data for the trial sites are presented in Table 02 .

\section{Treatments}

Nine IMBAs classified as growth boosters (Biozone, Gliogrow, Growmax, K-humate and Lanbac), partial replacements (Crop care and
Montys) or total replacements of conventional NPK fertiliser (Gromor and Promis) were selected and evaluated as recommended by the product manufacturer (Table 03). The growth boosters are distinguished as those IMBAs which received optimum recommended NPK fertiliser rate, while the partial and total replacements of NPK fertiliser are those with reduced NPK rate and no application of NPK fertiliser, respectively. An optimum conventionalNPKfertiliserrateandunamended plots were also included as controls at each site. The optimum conventional NPK rate at each trial site was based on soil test results during each planting season. The sources of $\mathrm{N}, \mathrm{P}$ and $\mathrm{K}$ were limestone ammonium nitrate, superphosphate and potassium chloride, respectively. Treatments were replicated four times and arranged in a randomised complete block design. Each treatment was applied on a $10 \mathrm{~m} \times 6 \mathrm{~m}$ plot. Prior to application, the IMBAs were chemically analysed (Table 04). Soil-applied IMBAs were broadcast uniformly over the respective plots and lightly worked into the soil with a hand hoe, while the foliar applied IMBAs were sprayed on plants as recommended under Table 03 using a CP15 knapsack sprayer.

\section{Land husbandry and crop history}

Seedbed preparation at the different trial sites was done by mouldboard ploughing, disking and harrowing. After each harvesting time, maize stubble was ploughed in with a rotavator and the trial sites left bare until the next planting. Just after planting, trials were sprayed with a two L Dual (S-metolachlor) $\mathrm{ha}^{-1}$ to destroy upcoming weeds and kept weed free during the growing season through mechanical weeding when necessary. Prior to the trials, wheat was grown at Bethlehem, sunflower at Bothaville and cowpea at both Ottosdal and Potchefstroom.

\section{Soil sampling and analyses}

\section{Chemical soil properties}

Before trial establishment, 10 random soil samples were collected from $0-20 \mathrm{~cm}$ soil 
depths using a soil auger, bulked and mixed included soil $\mathrm{pH}$, organic $\mathrm{C}$, available $\mathrm{N}$ and thoroughly to obtain a composite sample. P. Standard procedures were used to determine Soil analyses results were shown in Table $\mathrm{pH}\left(\mathrm{H}_{2} \mathrm{O}, 1: 2.5\right)$, organic $\mathrm{C}$ (Walkley and 01. A post-harvest soil sampling was also Black, 1934), available $\mathrm{N}\left(0.1 \mathrm{~N} \mathrm{~K}_{2} \mathrm{SO}_{4}\right)$ and conducted at the same soil depth from all plots Bray 1- P (Non-affiliated Soil Analyses Work in each site and season. Sample determination Committee, 1990).

Table 01. Geographic and soil characteristics of the trial sites

\begin{tabular}{|c|c|c|c|c|}
\hline Characteristics & Bethlehem & Bothaville & Ottosdal & Potchefstroom \\
\hline \multicolumn{5}{|l|}{ Geographic } \\
\hline Latitude & $28^{\circ} 23^{\prime}$ & $26^{\circ} 62^{\prime}$ & $26^{\circ} 08^{\prime}$ & $27^{\circ} 09^{\prime}$ \\
\hline Longitude & $-28^{\circ} 23^{\prime}$ & $-27^{\circ} 38^{\prime}$ & $-26^{\circ} 81^{\prime}$ & $-27^{\circ} 7^{\prime}$ \\
\hline Altitude (m) & 1850 & 1317 & 1587 & 1355 \\
\hline \multicolumn{5}{|l|}{ Soil $^{1}$} \\
\hline Soil depth (m) & 1.6 & 1.8 & 2.1 & 1.8 \\
\hline Soil form & Plinthic Lixisol & Plinthic Lixisol & Rhodic Ferrasal & Aeric Plinthisol \\
\hline \multicolumn{5}{|l|}{ Soil textural } \\
\hline Clay & 14 & 8 & 12 & 34 \\
\hline Silt $\} \%$ & 11 & 1 & 7 & 17 \\
\hline Sand & 75 & 91 & 81 & 49 \\
\hline $\mathrm{pH}\left(\mathrm{H}_{2} \mathrm{O}\right)$ & 5.47 & 7.02 & 5.83 & 6.61 \\
\hline Organic C $\quad(\%)$ & 0.43 & 0.20 & 0.38 & 0.82 \\
\hline $\mathrm{N}$ & 2.9 & 0.9 & 2.8 & 5.7 \\
\hline$\} m g \mathrm{~kg}^{-1}$ & 19 & 22 & 16 & 56 \\
\hline J & 112 & 74 & 135 & 192 \\
\hline ECEC $\quad \mathrm{cmol}(+) \mathrm{kg}^{-1}$ & 12.7 & 6.18 & 22.5 & 14.7 \\
\hline
\end{tabular}

${ }^{1}$ Classified according to Soil Classification Working Group (1991) and analyses data for samples from 0-20 cm depths.

Table 02. Climatic data for the three production seasons and on the long-term at the four ecotopes

\begin{tabular}{|c|c|c|c|c|c|c|c|c|c|c|c|c|c|}
\hline \multirow[b]{2}{*}{ Localities } & \multirow[b]{2}{*}{ Month } & \multicolumn{3}{|c|}{ Rain } & \multicolumn{3}{|c|}{ Tn } & \multicolumn{3}{|c|}{$\mathbf{T x}$} & \multicolumn{3}{|c|}{ A-pan } \\
\hline & & $\begin{array}{l}2006- \\
2007\end{array}$ & $\begin{array}{l}2007- \\
2008\end{array}$ & $\begin{array}{l}2008- \\
2009\end{array}$ & $\begin{array}{l}2006- \\
2007\end{array}$ & $\begin{array}{l}2007- \\
2008\end{array}$ & $\begin{array}{l}2008- \\
2009\end{array}$ & $\begin{array}{l}2006- \\
2007\end{array}$ & $\begin{array}{l}2007- \\
2008\end{array}$ & $\begin{array}{l}2008- \\
2009\end{array}$ & $\begin{array}{l}2006- \\
2007\end{array}$ & $\begin{array}{l}2007- \\
2008\end{array}$ & $\begin{array}{l}2008- \\
2009\end{array}$ \\
\hline \multirow{2}{*}{ Bethlehem } & $\begin{array}{l}\text { Annual } \\
\text { totals }\end{array}$ & 321.1 & 693.9 & 1131.8 & 7.2 & 7.0 & 7.2 & 23.4 & 21.8 & 23.6 & 4.3 & 3.7 & 5.3 \\
\hline & Long-term & 718 & 718 & 718 & 8.4 & 8.4 & 8.4 & 24.0 & 24.0 & 24.0 & 4.4 & 4.4 & 4.4 \\
\hline \multirow[t]{2}{*}{ Bothaville } & $\begin{array}{l}\text { Annual } \\
\text { totals }\end{array}$ & 489.5 & 561.0 & 580.1 & 7.3 & 8.4 & 8.6 & 27.0 & 25.6 & 27.2 & 5.4 & 4.8 & 5.0 \\
\hline & Long-term & 502 & 502 & 502 & 9.9 & 9.9 & 9.9 & 27.4 & 27.4 & 27.4 & 5.4 & 5.4 & 5.4 \\
\hline \multirow[t]{2}{*}{ Ottosdal } & $\begin{array}{l}\text { Annual } \\
\text { totals }\end{array}$ & 332.6 & 460.4 & 485.9 & 9.3 & 9.1 & 8.8 & 26.4 & 26.9 & 26.3 & 5.5 & 3.9 & 4.1 \\
\hline & Long-term & 593 & 593 & 593 & 10.3 & 10.3 & 10.3 & 27.1 & 27.1 & 27.1 & 5.5 & 5.5 & 5.5 \\
\hline \multirow[t]{2}{*}{$\begin{array}{l}\text { Potchefst- } \\
\text { room }\end{array}$} & $\begin{array}{l}\text { Annual } \\
\text { totals }\end{array}$ & 643.4 & 651.1 & 547.3 & 10.0 & 10.8 & 9.9 & 26.5 & 25.0 & 26.7 & 5.3 & 4.6 & 4.4 \\
\hline & Long-term & 622 & 622 & 622 & 10.7 & 10.7 & 10.7 & 25.2 & 25.2 & 25.2 & 5.3 & 5.3 & 5.3 \\
\hline
\end{tabular}

Rain $=$ annual mean rainfall $(\mathrm{mm}) ; \mathrm{Tn}=$ Daily mean minimum temperature $\left({ }^{\circ} \mathrm{C}\right) ; \mathrm{Tx}=$ Daily mean maximum temperature $\left({ }^{\circ} \mathrm{C}\right)$; A Pan $=$ Daily mean evaporation $(\mathrm{mm})$. 
Table 03. IMBAs selected for evaluation at four sites

\begin{tabular}{|c|c|c|c|}
\hline $\begin{array}{l}\text { Category of } \\
\text { IMBAs }\end{array}$ & IMBAs & $\begin{array}{l}\text { Application } \\
\text { method }\end{array}$ & Recommendations \\
\hline \multirow{5}{*}{ Growth boosters } & Biozone & Soil application & $\begin{array}{l}\text { Optimum fertiliser rate (OFR) depending on soil } \\
\text { test results of the site }+10 \mathrm{~L} \mathrm{ha}^{-1} \text { at planting }\end{array}$ \\
\hline & Gliogrow & $\begin{array}{l}\text { Seed dressing } \\
+ \text { foliar } \\
\text { application }\end{array}$ & $\begin{array}{l}100 \% \text { OFR }+0.2 \mathrm{~L} \mathrm{ha}^{-1} \text { of both Maxiflo + Trykocide } \\
+0.1 \mathrm{~L} \mathrm{ha}{ }^{-1} \text { of Teprosyn } \mathrm{Zn} / \mathrm{P} \text { per } 25 \mathrm{~kg} \text { seeds; } 0.4 \\
\mathrm{~L} \mathrm{ha}^{-1} \text { of both Maxiflo + Trykocide four weeks after } \\
\text { emergence }\end{array}$ \\
\hline & Growmax & Soil application & Blend with inorganic fertiliser to supply $100 \%$ OFR \\
\hline & K-humate & Soil application & $100 \%$ OFR $+20 \mathrm{~kg} \mathrm{ha}^{-1}$ a week prior to planting \\
\hline & Lanbac & Soil application & $\begin{array}{l}100 \% \text { OFR }+10 \mathrm{~L} \mathrm{ha}^{-1} \mathrm{MS} \text { Humate }+2 \mathrm{~kg} \mathrm{ha}^{-1} \mathrm{Mi}- \\
\text { croboost }+2 \mathrm{~L} \mathrm{ha}^{-1} \text { Microbial inoculants at planting }\end{array}$ \\
\hline \multirow[t]{2}{*}{$\begin{array}{l}\text { Partial } \\
\text { replacement of } \\
\text { NPK fertiliser }\end{array}$} & Crop care & $\begin{array}{l}\text { Soil + foliar ap- } \\
\text { plication }\end{array}$ & $\begin{array}{l}70 \% \text { OFR }+400 \mathrm{~kg} \mathrm{ha}^{-1} \text { Growmax }+5 \mathrm{~L} \mathrm{ha}^{-1} \text { Agri- } \\
\text { balance at planting; } 2.5 \mathrm{~L} \mathrm{ha}^{-1} \text { Agri-boost }+ \text { Agri- } \\
\text { Zinc at } 4 \text { weeks after planting; } 2 \mathrm{~L} \mathrm{ha}{ }^{-1} \text { Agri-fulbor } \\
\text { at tasseling }\end{array}$ \\
\hline & Montys & Soil application & $50 \%$ OFR $+3 \mathrm{~L} \mathrm{ha}^{-1}$ at planting \\
\hline \multirow{2}{*}{$\begin{array}{l}\text { Total replacement } \\
\text { of NPK fertiliser }\end{array}$} & Gromor & Soil application & $2000 \mathrm{~kg} \mathrm{ha}^{-1}$ at planting; \\
\hline & Promis & Soil application & $1000 \mathrm{~kg} \mathrm{ha}^{-1}$ at planting; \\
\hline
\end{tabular}

Table 04. Chemical composition of the different IMBAs used for evaluation

\begin{tabular}{llllllllll}
\hline Category of IMBAs & IMBAs & $\begin{array}{l}\mathbf{p H} \\
\left(\mathbf{H}_{2} \mathbf{O}\right)\end{array}$ & $\begin{array}{l}\mathbf{N} \\
\left(\mathrm{mg} \mathrm{kg}^{-1}\right)\end{array}$ & $\mathbf{P}$ & $\mathbf{K}$ & $\mathbf{C a}$ & $\mathbf{M g}$ & $\mathbf{N a}$ & $\begin{array}{l}\text { Organic C } \\
(\%)\end{array}$ \\
\hline Growth boosters & Biozone & 3.1 & 0.02 & 0.01 & 0.01 & 1.00 & 0.01 & 2.75 & 2.15 \\
& Gliogrow & 4.0 & 0.21 & 0.01 & 0.01 & 0.13 & 0.13 & 1.25 & 0.43 \\
& Growmax & 6.8 & 3.00 & 3.00 & 3.00 & 1.38 & 0.88 & 1.75 & 28.3 \\
& K humate & 9.6 & 6.92 & 17.6 & 101.0 & 7.50 & 1.25 & 12.0 & $>60$ \\
& Lanbac & 5.1 & 0.38 & 0.58 & 2.50 & 1.00 & 0.38 & 4.25 & 3.80 \\
Partial replacement of & Crop care & 8.1 & 0.96 & 1.17 & 4.13 & 0.63 & 0.38 & 7.00 & 2.66 \\
NPK fertiliser & Montys & 9.5 & 0.45 & 1.17 & 0.13 & 1.75 & 0.50 & 5.00 & 3.33 \\
Total replacement of & Gromor & 6.0 & 3.80 & 16.0 & 20.0 & 0.30 & 5.00 & 1.00 & 35.8 \\
NPK fertiliser & Promis & 5.8 & 4.00 & 1.60 & 1.80 & 3.25 & 0.70 & 0.08 & 42.9 \\
\hline
\end{tabular}

${ }^{1}$ Grouping of IMBAs based on conventional NPK rate used with the IMBA consist of growth boosters (Biozone, Gliogrow, Growmax, K-humate and Lanbac), partial replacements (Crop care and Montys) or total replacements of NPK (Gromor and Promis)

\section{Microbial biomass indicators}

Soil samples were taken from $0-10 \mathrm{~cm}$ soil depths within an area of $4 \mathrm{~m}^{2}$ at randomly selected positions in each plot using a $10 \mathrm{~mm}$ diameter core sampler, pooled and thoroughly mixed to obtain a composite sample. The sampling was done first at four weeks after planting, at flowering and crop harvest for microbial biomass- $\mathrm{C}\left(\mathrm{C}_{\text {mic }}\right)$ determination. All composite samples were sieved through a 2 $\mathrm{mm}$ stainless steel sieve to eliminate stones and plant roots, and thereafter stored at $4^{\circ} \mathrm{C}$ prior to analyses. Biomass-C was determined following the chloroform fumigationextraction procedure (Vance et al., 1987).

\section{Statistical analyses}

Analyses of variance using GenStat Release 14 were calculated from data obtained in the trials. Differences in treatment effects were 
considered to be statistically significant at $\mathrm{P}$ $<0.05$ with the Tukey honestly significant difference (HSD) post-hoc test.

\section{RESULTS AND DISCUSSION}

The sites varied greatly in terms of geographic and soil characteristics (Table 01). The longterm mean annual rainfall varied between 502 $\mathrm{mm}$ at Bothaville and $718 \mathrm{~mm}$ at Bethlehem (Table 02). Equally, annual rainfall at the four sites was very variable during the study period. Average daily minimum temperature across the sites ranged from 8 to $11^{\circ} \mathrm{C}$ and 24 to $27^{\circ} \mathrm{C}$ for the mean daily maximum temperature. Mean daily evaporation at the sites conformed to the long-term daily averages of 4.4 to $5.4 \mathrm{~mm}$. Table 04 present the nutritional composition of the IMBAs used in the study. The chemical analyses of the IMBAs showed a wide $\mathrm{pH}_{(\mathrm{H} 2 \mathrm{O})}$ range of 3.1 with Biozone to 9.6 with K-humate. The organic $\mathrm{C}$ content varied between $0.43 \%$ with Gliogrow and $>$ $60 \%$ with K-humate, and with very low NPK contents across the IMBAs.

\section{Chemical properties}

Application of the IMBAs showed variable and significant $(p<0.05)$ effects on selected soil quality indices such as soil $\mathrm{pH}$, organic $\mathrm{C}$, available $\mathrm{N}$ and $\mathrm{P}$ (Tables 05 and 06).

\section{Soil pH}

Application of the various IMBA types showed a depressive effect on post-harvest soil $\mathrm{pH}$ across the ecotopes and soil types than their pre-plant situation (Table 01). Only application of growth boosters such as Gliogrow and Growmax, and total replacement like Gromor showed increased soil $\mathrm{pH}$ values at Bethlehem ecotope (Table 05). The lower soil $\mathrm{pH}$ could be attributed to microbial decomposition releasing of organic acids as suggested by Fan et al., 2007 as well as the conventional NPK fertiliser that was either applied or contained in the IMBAs in various amounts. The ammonium released from either the inorganic or organic fraction of
IMBAs may have also enhanced acidification due to possible nitrification took place (Wong et al., 1992; Somani and Totawat, 1996; Belay et al., 2002). Consequently, the lower soil $\mathrm{pH}$ could be ascribed to the soil's lower clay and organic $\mathrm{C}$ content across the ecotopes, although moderately higher clay content at Potchefstroom. Curtin and Trolove (2013) showed in a 12-year study that soil's buffer capacity (measured using $\mathrm{KOH}$ ) was strongly correlated with soil organic $\mathrm{C}\left(R^{2}=0.76\right)$ and weakly (but significantly, $P<0.05$ ) with clay content. Likewise, they showed that soil with low soil $\mathrm{C}$ concentrations tended to be more acidic, possibly partly due to weaker $\mathrm{pH}$ buffering. Amongst the IMBA categories, soil $\mathrm{pH}$ was higher coming to neutral range in the order total replacements $>$ growth boosters > partial replacements. However, only Gromor and Gliogrow applications showed significantly $(\mathrm{P}<0.05)$ increased $\mathrm{pH}$ values than in the NPK plots both in higher rainfall and cooler sites of Bethlehem and Potchefstroom ecotopes. Equally, soil $\mathrm{pH}$ increased significantly regardless of the IMBA category in light textured soil of $8 \%$ clay typical of the Bothaville ecotope. The high $\mathrm{pH}$ in the IMBA plots at Bothaville therefore indicates that the soil was saturated to a larger extent with basic cations (Triantafilis et al., 2003). Notwithstanding, the Ottosdal ecotope also comprised light-textured soil of $12 \%$ clay as for Bothaville, however soil $\mathrm{pH}$ amongst the IMBAs decreased in many instances than in the NPK check. This decrease could be attributed to the sites soil's lower CEC concentration that could have led to the crop removal of the level of bases of calcium, magnesium, potassium, etc. in the soil water and the inability of the soil to adequately replenish the supply. Equally, the site was also previously planted to a legume. Legume crops like soybeans, cowpeas etc. tend to take up more divalent cations and as a result, excrete $\mathrm{H}^{+}$ions from their roots to maintain electrochemical balance within their tissues that subsequent results in a net soil acidification (Aguilar and van Diest, 
1981). Soil acidity is controlled by the amount that is either contained in, or generated by the of hydrogen $\left(\mathrm{H}^{+}\right)$and the aluminum $\left(\mathrm{Al}^{+++}\right)$soil and soil components (Bolan et al., 2003).

Table 05. Average of three years values on post-harvest soil $\mathrm{pH}$ and organic $\mathrm{C}$ during three seasons at four sites as affected by IMBAs

\begin{tabular}{|c|c|c|c|c|c|c|c|c|c|}
\hline \multirow[b]{2}{*}{$\begin{array}{l}\text { Category of } \\
\text { IMBAs }\end{array}$} & \multirow[b]{2}{*}{ IMBAs } & \multicolumn{4}{|c|}{ pH } & \multicolumn{4}{|c|}{ Organic C (\%) } \\
\hline & & $\begin{array}{l}\text { Beth- } \\
\text { lehem }\end{array}$ & $\begin{array}{l}\text { Bo- } \\
\text { thaville }\end{array}$ & $\begin{array}{l}\text { Ot- } \\
\text { tosdal }\end{array}$ & $\begin{array}{l}\text { Potchefst- } \\
\text { room }\end{array}$ & $\begin{array}{l}\text { Beth- } \\
\text { lehem }\end{array}$ & $\begin{array}{l}\text { Bo- } \\
\text { thaville }\end{array}$ & $\begin{array}{l}\text { Ottos- } \\
\text { dal }\end{array}$ & $\begin{array}{l}\text { Potchef- } \\
\text { stroom }\end{array}$ \\
\hline \multirow{5}{*}{$\begin{array}{l}\text { Growth } \\
\text { boosters }\end{array}$} & Biozone & 5.34 & 6.20 & 5.55 & 5.77 & 0.49 & 0.31 & 0.50 & 0.77 \\
\hline & Gliogrow & 5.68 & 6.45 & 5.57 & 6.01 & 0.49 & 0.32 & 0.53 & 0.80 \\
\hline & Growmax & 5.56 & 6.24 & 5.48 & 5.97 & 0.48 & 0.30 & 0.51 & 0.79 \\
\hline & K-humate & 5.40 & 6.27 & 5.47 & 5.88 & 0.51 & 0.32 & 0.49 & 0.81 \\
\hline & Lanbac & 5.37 & 6.21 & 5.28 & 5.86 & 0.50 & 0.30 & 0.50 & 0.79 \\
\hline \multirow{2}{*}{$\begin{array}{l}\text { Partial } \\
\text { replacement of } \\
\text { NPK fertiliser }\end{array}$} & Crop care & 5.35 & 6.21 & 5.29 & 5.82 & 0.48 & 0.35 & 0.50 & 0.83 \\
\hline & Montys & 5.45 & 6.23 & 5.46 & 5.79 & 0.50 & 0.31 & 0.51 & 0.80 \\
\hline \multirow{6}{*}{$\begin{array}{l}\text { Total } \\
\text { replacement of } \\
\text { NPK fertiliser }\end{array}$} & Gromor & 5.79 & 6.41 & 5.63 & 6.12 & 0.48 & 0.30 & 0.49 & 0.82 \\
\hline & Promis & 5.43 & 6.24 & 5.67 & 5.92 & 0.49 & 0.32 & 0.49 & 0.82 \\
\hline & NPK & 5.44 & 5.99 & 5.60 & 5.83 & 0.45 & 0.22 & 0.39 & 0.81 \\
\hline & $\begin{array}{l}\text { Untreated } \\
\text { Con rol }\end{array}$ & 5.44 & 5.95 & 5.29 & 5.89 & 0.45 & 0.20 & 0.38 & 0.76 \\
\hline & SEM & 0.089 & 0.071 & 0.053 & 0.071 & 0.027 & 0.026 & 0.021 & 0.018 \\
\hline & $\mathrm{LSD}_{\mathrm{T}(0.05)}$ & 0.183 & 0.144 & 0.109 & 0.145 & 0.055 & 0.053 & 0.042 & 0.037 \\
\hline
\end{tabular}

Table 06. Average of three years values on post-harvest available $N$ and $P$ during three seasons at four sites as affected by IMBAs

\begin{tabular}{|c|c|c|c|c|c|c|c|c|c|}
\hline \multirow[b]{2}{*}{$\begin{array}{l}\text { Category of } \\
\text { IMBAs }\end{array}$} & \multirow[b]{2}{*}{ IMBAs } & \multicolumn{4}{|c|}{ Available N (mg kg-1) } & \multicolumn{4}{|c|}{ Available P (mg kg $\left.{ }^{-1}\right)$} \\
\hline & & Bethlehem & Bothaville & Ottosdal & $\begin{array}{l}\text { Potchefst- } \\
\text { room }\end{array}$ & Bethlehem & Bothaville & Ottosdal & $\begin{array}{l}\text { Potchefst- } \\
\text { room }\end{array}$ \\
\hline \multirow{5}{*}{$\begin{array}{l}\text { Growth } \\
\text { boosters }\end{array}$} & Biozone & 3.56 & 1.97 & 2.40 & 3.47 & 34.7 & 25.3 & 34.7 & 59.3 \\
\hline & Gliogrow & 3.41 & 2.09 & 2.71 & 4.59 & 36.2 & 28.2 & 32.1 & 59.8 \\
\hline & Growmax & 2.09 & 1.84 & 2.39 & 2.57 & 35.3 & 27.0 & 35.5 & 56.3 \\
\hline & K-humate & 2.48 & 2.43 & 3.06 & 3.08 & 29.4 & 25.3 & 38.3 & 57.5 \\
\hline & Lanbac & 3.67 & 2.19 & 2.14 & 2.86 & 39.2 & 25.0 & 37.3 & 55.1 \\
\hline \multirow{2}{*}{$\begin{array}{l}\text { Partial re- } \\
\text { placement of } \\
\text { NPK fertiliser }\end{array}$} & Crop care & 2.08 & 2.51 & 2.68 & 3.80 & 39.1 & 27.9 & 36.6 & 64.5 \\
\hline & Montys & 2.63 & 1.97 & 2.05 & 3.60 & 30.9 & 27.3 & 31.5 & 62.2 \\
\hline \multirow{6}{*}{$\begin{array}{l}\text { Total replace- } \\
\text { ment of NPK } \\
\text { fertiliser }\end{array}$} & Gromor & 2.50 & 1.74 & 1.93 & 2.25 & 34.9 & 25.5 & 31.9 & 60.5 \\
\hline & Promis & 1.96 & 1.76 & 2.22 & 1.86 & 31.8 & 25.8 & 27.3 & 62.5 \\
\hline & NPK & 2.44 & 1.95 & 2.03 & 2.91 & 34.8 & 25.4 & 41.6 & 62.6 \\
\hline & $\begin{array}{l}\text { Untreated } \\
\text { Control }\end{array}$ & 1.47 & 0.80 & 1.53 & 1.13 & 16.9 & 21.8 & 14.8 & 53.7 \\
\hline & SEM & 0.530 & 0.234 & 0.544 & 0.810 & 4.236 & 2.381 & 5.673 & 3.100 \\
\hline & $\mathrm{LSD}_{\mathrm{T}(0.05)}$ & 1.082 & 0.478 & 1.111 & 1.654 & 8.650 & 4.863 & 11.59 & 6.333 \\
\hline
\end{tabular}




\section{Organic C}

The content of post-harvest organic $\mathrm{C}$ significantly $(\mathrm{P}<0.05)$ increased regardless of the IMBA type in the light-textured soils of Bothaville and Ottosdal ecotopes, while only $\mathrm{K}$-humate used as a growth booster showed significant $(\mathrm{P}<0.05)$ higher organic $\mathrm{C}$ values than in the NPK check plots at the lighttextured soil of Bethlehem ecotope (Table 05). Amongst the different IMBA types, postharvest organic $\mathrm{C}$ content in light-textured ( $8-14 \%$ clay) increased by 5 to 8 units at Bethlehem, 9 to 11 units at Bothaville and 11 to 15 units at Ottosdal soils, but only increased by a unit at Potchefstroom site (34\% clay) than their pre-plant contents. The fact that organic $\mathrm{C}$ content at Potchefstroom increased by a unit could be related to the soils moderately higher CEC and clay content indicating that the soil had a higher soil organic cation level to provide adequate crop nutrition. A substantial decrease in $\mathrm{pH}$ buffering (by up to $24 \%$ in top $7.5 \mathrm{~cm}$ ) was associated with a decline in SOM following the conversion of permanent pasture (pre-trial land use) to arable cropping (Curtin and Trolove, 2013). Equally, the only increased organic $\mathrm{C}$ content manifested in heavier-textured soil of Potchefstroom ecotope resulted with applications of both total replacements of NPK IMBAs and the application of partial replacement like Crop care. Long-term application of organic amendments increased organic $\mathrm{C}$ by up to $90 \%$ and $100 \%$ when unfertilised soil and inorganic fertilised soil served as references, respectively (Diacono and Montemurro, 2010). This demonstrates that incorporation of organic fertiliser into the soil could be an efficient way of maintaining a desired soil $\mathrm{C}$ level (Fan et al., 2007).

\section{Available N}

The various IMBAs applied exerted a positive effect on post-harvest soil available $\mathrm{N}$ only in light-textured (8-14\% clay) soil of the Bethlehem, Bothaville and Ottosdal ecotopes (Table 06). This augmented available $\mathrm{N}$ value is ascribed to the increased organic $\mathrm{C}$ content at the respective sites. Although, the Potchefstroom site's high clay content was able to retain significant quantities of the plant nutrient (Diepen and van der Wal, 1995), there was a decrease in available $\mathrm{N}$ content which is associated with decrease of organic $\mathrm{C}$ level (Okwuagwu et al., 2003). The available $\mathrm{N}$ content amongst the IMBA categories were increased in the order growth boosters $>$ partial replacements $>$ total replacements. The higher available $\mathrm{N}$ from IMBAs used either as growth boosters or partial replacements are possibly due to synergy (Bokhtiar and Sakurai, 2005; Boateng et al., 2006). Comparing, to the NPK standard, significantly $(\mathrm{P}<0.05)$ increased available $\mathrm{N}$ content resulted in light-textured soil with growth booster applications like Biozone and Lanbac at Bethlehem, K-humate at Bothaville, and a partial replacement of NPK IMBA like Crop care at Bothaville, while only Gliogrow showed significantly $(\mathrm{P}<0.05)$ increased $\mathrm{N}$ content in heavier-textured soil of Potchefstroom ecotope. The available N content from both total replacement of NPK plots were insignificant than in the NPK check plots and was also consistently lower than the other active ingredients of IMBAs due to their slower $\mathrm{N}$ releasing potential (Belay et al., 2002).

\section{Available P}

Significant $(\mathrm{P}<0.05)$ increased post-harvest available $\mathrm{P}$ content than in the NPK check plots manifested from applications of either growth boosters or partial replacements of NPK fertiliser respectively in higher rainfall typical of the Bethlehem and Potchefstroom ecotopes, while only Crop care applied as a partial replacement of NPK showed significant $(\mathrm{P}<0.05)$ increased available $\mathrm{P}$ content at Potchefstroom ecotope (Table 06). Application of both total replacements of NPK IMBAs showed insignificantly higher P content than any of the growth boosters in heavy-textured soil. Okwuagwu et al. (2003) reported higher available $\mathrm{P}$ in organic fertilised plots as a result of the long-term residual effect. 


\section{Microbial biomass indicators}

The effect of the various categories of IMBAs showed statistical insignificant effects on biomass-C relative to the NPK check, but was significant $(\mathrm{P}<0.05)$ in few instances at both soil types and samplings compared to the untreated control (Table 07). Generally, use of the various IMBAs showed pronounced immobilisation fluxes at both soil types at 4-weeks after planting relative to the two standards. The predominant $\mathrm{C}_{\text {mic }}$ immobilisation at 4-weeks after planting regardless of the IMBA treatment across the ecotopes could be attributed to the resistance of biological amendments to microbial decomposition (Fan et al., 2007). This could further be associated to wet soil conditions (Ponnamperuma, 1972) and/or competition for nutrients by crop roots and microorganisms (Bhattacharyya et al. 2003).

The use of the different IMBAs generally showed higher $\mathrm{C}_{\text {mic }}$ mineralisation fluxes than in the two checks at flowering stage in both soil types, being generally higher in heavy-textured soil of Potchefstroom ecotope. Similar pattern manifested at crops harvest, however $\mathrm{C}_{\text {mic }}$ mineralisation fluxes were reduced than in the NPK check from applications of both partial replacements of NPK IMBAs, except for Montys respectively at sites previously grown to legumes typical of Ottosdal and Potchefstroom ecotopes. The higher $\mathrm{C}_{\text {mic }}$ mineralisation at Potchefstroom could be attributed to the site's high clay content that correspond with high nutrient levels (Van Veen et al., 1985). Biomass-C mineralisation fluxes in the different IMBA plots were largely greater in sites with low and erratic rainfall such as Bothaville and Ottosdal than in higher and cooler rainfall area such as at Bethlehem and Potchefstroom ecotopes. The increased $\mathrm{C}_{\text {mic }}$ mineralisation at flowering and crop harvest is attributed inter alia to drier soil conditions with higher temperatures. Neff and Hooper (2002) asserted that $\mathrm{C}_{\text {mic }}$ decomposition increases with temperature raising the possibility of significant $\mathrm{C}$ release and with microbial proliferation and activity (Hu and Cao, 2007).

Table 07. Average of three years values on microbial biomass- $C\left(\mu \mathrm{g} \mathbf{C ~ g}^{-1}\right)$ at three samplings during three seasons at four sites as affected by IMBAs

\begin{tabular}{|c|c|c|c|c|c|c|c|c|c|c|c|c|c|}
\hline \multirow[b]{2}{*}{$\begin{array}{l}\text { Category } \\
\text { of IMBAss }\end{array}$} & \multirow[b]{2}{*}{ IMBAs } & \multicolumn{4}{|c|}{4 weeks after planting } & \multicolumn{4}{|c|}{ Flowering } & \multicolumn{4}{|c|}{ Crop harvest } \\
\hline & & $\begin{array}{l}\text { Bethle- } \\
\text { hem }\end{array}$ & $\begin{array}{l}\text { Bo- } \\
\text { thaville }\end{array}$ & $\begin{array}{l}\text { Ottos- } \\
\text { dal }\end{array}$ & Potch & $\begin{array}{l}\text { Bethle- } \\
\text { hem }\end{array}$ & $\begin{array}{l}\text { Bo- } \\
\text { thaville }\end{array}$ & $\begin{array}{l}\text { Ottos- } \\
\text { dal }\end{array}$ & Potch & $\begin{array}{l}\text { Bethle- } \\
\text { hem }\end{array}$ & $\begin{array}{l}\text { Bo- } \\
\text { thaville }\end{array}$ & $\begin{array}{l}\text { Ottos- } \\
\text { dal }\end{array}$ & Potch \\
\hline \multirow{5}{*}{$\begin{array}{l}\text { Growth } \\
\text { boosters }\end{array}$} & Biozone & -137.3 & -159.8 & -105.4 & -135.5 & 204.8 & 175.6 & 198.3 & 269.4 & 185.10 & 36.70 & 55.07 & 42.53 \\
\hline & Gliogrow & -73.4 & -363.0 & -213.6 & -347.3 & 192.8 & 266.3 & 237.7 & 342.1 & 110.20 & 56.83 & 42.97 & 80.83 \\
\hline & Growmax & -310.1 & -75.7 & -150.9 & -381.3 & 192.8 & 232.9 & 221.7 & 251.1 & 126.40 & 40.80 & 39.93 & 0.83 \\
\hline & K-humate & -194.3 & -182.1 & -55.6 & -205.2 & 216.0 & 189.9 & 184.7 & 212.4 & 62.83 & 40.47 & 56.33 & 35.27 \\
\hline & Lanbac & -735.3 & -433.0 & -171.1 & -388.2 & 230.0 & 184.0 & 235.9 & 315.8 & 85.00 & 62.77 & 69.73 & 67.37 \\
\hline \multirow{2}{*}{$\begin{array}{l}\text { Partial } \\
\text { replace- } \\
\text { ment }\end{array}$} & Crop care & -102.0 & -163.6 & -63.4 & -153.1 & 188.3 & 201.7 & 212.4 & 268.2 & 73.23 & 18.83 & 18.07 & 30.43 \\
\hline & Montys & -395.4 & -325.5 & -100.7 & -438.0 & 197.2 & 285.4 & 151.9 & 265.5 & 91.37 & 1.27 & 50.03 & 121.77 \\
\hline \multirow{6}{*}{$\begin{array}{l}\text { Total re- } \\
\text { placement } \\
\text { of NPK }\end{array}$} & Gromor & -511.1 & -367.7 & -261.8 & -359.0 & 222.3 & 218.8 & 151.3 & 294.6 & 105.87 & 46.80 & 118.23 & 49.10 \\
\hline & Promis & -246.9 & -140.0 & -60.8 & -115.5 & 209.0 & 243.3 & 184.7 & 274.0 & 106.97 & 56.80 & 83.83 & 59.77 \\
\hline & NPK & -193.4 & -198.3 & -31.8 & -196.8 & 226.8 & 141.0 & 197.5 & 245.2 & 73.57 & 20.30 & 28.20 & 42.77 \\
\hline & Control & -164.8 & -186.0 & -20.4 & -48.5 & 165.9 & 107.5 & 133.7 & 208.7 & 13.93 & -12.30 & -12.97 & 15.10 \\
\hline & SEM & 287.2 & 163.8 & 111.2 & 201.0 & 38.5 & 60.0 & 45.5 & 52.8 & 48.10 & 38.17 & 49.30 & 49.27 \\
\hline & $\mathrm{LSD}_{\mathrm{T}(0.05)}$ & 829.5 & 473.1 & 321.2 & 564.2 & 111.3 & 173.3 & 131.5 & 152.4 & 138.9 & 98.9 & 142.4 & 142.3 \\
\hline
\end{tabular}

Potch $=$ Potchefstroom 


\section{CONCLUSIONS}

The different IMBAs exerted a profound positive effect on the selected soil quality indices of soil $\mathrm{pH}$, organic $\mathrm{C}$, available $\mathrm{N}$ and P. Application of IMBAs with optimum recommended NPK fertiliser rate (growth boosters) promoted acidity in soils compared to the use of IMBAs as either partial or total replacements of conventional NPK fertiliser. Application of all the differentIMBAcategories showed positive influence on organic $\mathrm{C}$ content only in light-textured soils. The use of IMBAs as growth boosters like Biozone, Gliogrow and K-humate, and with a partial replacement of NPK IMBA like Crop care augmented significant positive influence on available $\mathrm{N}$ across the sites. Soil available $\mathrm{P}$ was increased with application of either growth boosters or partial replacement of NPK at both soil types. The different IMBAs promoted higher $\mathrm{C}_{\text {mic }}$ immobilisation at 4-weeks after planting, but $\mathrm{C}_{\text {mic }}$ mineralisation was predominant at flowering and crop harvest, but tended to decline at crop harvest at both soil types. The steady immobilisation fluxes at 4-weeks after planting could therefore minimise leaching as nutrients are withheld until the appropriate time for crop utilisation.

\section{Acknowledgements}

This research was funded by Agricultural Research Council and Maize Trust, South Africa while technical support was provided by Molefe Thobakgale and Thato MatselaTsiu. The study bursary granted to the first author by Maize Trust is also immensely appreciated.

\section{REFERENCES}

Aguilar-Santelises, A. and Van Diest, A. (1981). Rock-phosphate mobilisation induced by the alkaline uptake pattern of legumes utilising symbiotically fixed nitrogen. Plant and Soil. 61: 27-42.

Baloyi, T.C., Kutu, F.R. and Du Preez, C.C. (2010). Assessment of variable application rates of biological amendment substances on establishment and growth characteristics of maize plants. African Journal Biotechnology. 9: 7847-7852.

Belay, A., Claassens, A.S. and Wehner, F.C. (2002). Influence of residual manure on selected nutrient elements, microbial properties and maize yield under long-term crop rotation. South African Journal of Plant Soil. 18: 1-6.

Bhattacharyya, P., Chakrabarti, K. and Chakraborty, A. (2003). Microbial biomass and enzyme activities in submerged rice soil amended with municipal solid waste compost and decomposed cow manure. Chemosphere. 60: 310-318.

Boateng, S.A., Zickermann, J. and Kornahrens, M. (2006). Poultry manure effect on growth and yield of maize. West African Journal Applied Ecology. 9: 11-18.

Bokhokhtiar, S.M. and Sakurai, K. (2005). Effects of organic manure and chemical fertiliser on soil fertility and productivity of plant and ratoon crops of sugarcane. Archives of Agronomy and Soil Science. 51: 325-334.

Bolan, N.S., Adriano, D.C. and Curtin, D. (2003) Soil acidification and liming interactions with nutrient and heavy metal transformation and bioavailability. Advances in Agronomy, 78:

215-272. 
Černý, J., Balík J, Pavlíková, D., Zitková, M. and Sýkora, K. (2003). The influence of organic and mineral nitrogen fertilisers on microbial biomass nitrogen and extractable organic nitrogen in long-term experiments with maize. Plant Soil and Environment. 49: 560-64.

Curtin, D. and Trolove, S. (2013). Predicting pH buffering capacity of New Zealand soils from organic matter content and mineral characteristics. Soil Research, 51(6): 494-502.

Diacono, M. and Montemurro, F. (2010). Long-term effects of organic amendments on soil fertility. A review. Agronomy Sustainable and Development. 30: 401-422.

Diepen, C.A. and Van Der Wal, T. (1995). Crop growth monitoring and yield forecasting at regional and national scale. In: Proceedings workshop for central and eastern Europe on agrometeorological models: theory and applications in the MARS project (Dallemand, J. F. and Vossen, P. Eds.), Ispra. Italy, 143-157.

Fan, T., Xu, M., Zhou, G. and Ding, L. (2007). Trends in grain yields and soil organic carbon in a long-term fertilisation experiment in the China Loess Plateau. AM-Euras. Journal of Agriculture and Environmental Science. 2: 600-610.

Gilani, S.S. and Bahmanyar, M.A. (2008). Impact of organic amendments with and without mineral fertilisers on soil microbial respiration. Journal of Applied Science. 8: 642-647.

Goshal, N. and Singh, K.P. (1995). Effects of farmyard manure and inorganic fertiliser on the dynamics of soil microbial biomass in a tropical dryland agro-ecosystem. Biology, Fertility and Soils. 19: 231-238.

Heisey, P.W. and Mwangi, W.M. (1996). Fertiliser use and maize production in sub-Saharan Africa. Economics Working Paper, Mexico, CIMMYT, 34pp.

Hossain, M. and Singh, V.P. (2000). Fertiliser use in Asian agriculture: implications for sustaining food security and the environment. Nutrient Cycling and Agrosystem. 57: 155-169.

Hu, C. and Cao, Z. (2007). Size and activity of the soil microbial biomass and soil enzyme activity in long-term field experiments. World Journal Agriculture Science. 3: 63-70.

Kutu, F.R. (2012). Effect of conservation agriculture management practices on maize productivity and selected soil quality indices under South African dryland conditions. African Journal of Agricultural Research. 7: 3839-3846.

Laker, M.C. (1976). Soil fertility and the potential for increased crop production in the South African homelands. Fertiliser Society of South African Journal. 2: 21- 24.

Mills, A.J. and Fey, M.V. (2003). Declining soil quality in South Africa: Effects of land use on soil organic matter and surface crusting. South African Journal of Science, 99: 429-436.

Mnkeni, P.N.S. and Mkile, Z. (2006). Characterisation of kraal manure and optimisation of its use as fertiliser in the eastern Cape Province. In: Smallholder farming and soil fertility management in the eastern Cape, South Africa (Van Averbeke, W., Harris, P., van Ranst, E., Mnkeni, P. and Verplancke, H. Eds.): Chapter 8. Pretoria, UNISA Press.

Neff, J.C. and Hooper, D.U. (2002). Vegetation and climate controls on potential $\mathrm{CO}_{2}$, DOC and DON production in northern latitude soils. Global Change Biology. 8: 872-884. 
Non-Affiliated Soil Analyses Work Committee. (1990). Handbook of Standard Soil Testing Methods for Advisory Purposes. Soil Science Society of South Africa, Pretoria.

Okwuagwu, M.I., Alleh, M.E. and Osemwota, I.O. (2003). The effects of organic and inorganic manure on soil properties and yield of okra in Nigeria. African Crop Science Conference Proceedings. 6: 390-393.

Onwonga, R.N., Lelei, J.J. and Mochoge, B.B. (2010). Mineral nitrogen and microbial biomass dynamics under different acid soil management practices for maize production. Journal of Agricultural Science. 2: 16-30.

Ponnamperuma, F.N. (1972). The chemistry of submerged soils. Advances in Agronomy. 24: 26-92.

Primavesi, A. (1990). Soil life and chemical fertilisers. ILEIA Newsletter. 6:1-2.

Soil Classification Working Group. (1991). Soil classification: A taxonomic system for South Africa. Memoirs on the Agricultural Natural Resources of South Africa No 15, Department of Agricultural Development, Pretoria, South Africa.

Somani, L.L. and Totawat, K.L. (1996). Soil conditioners and amendments. $1^{\text {st }}$ edition Agrotech Pub. Academy, Udaipur. 28-160.

Triantafilis, J., Huckel, A.I. and Odeh, I.O.A. (2003). Field-scale assessment of deep drainage risk. Irrigation Science. 21, 183-192.

Van Veen, J.A., Ladd, J.N. and Amato, M. (1985). Turnover of carbon and nitrogen through the microbial biomass in a sandy loam and a clay soil incubated with $\left[{ }^{14} \mathrm{C}(\mathrm{U})\right]$ glucose and $\left[{ }^{15} \mathrm{~N}\right]\left(\mathrm{NH}_{4}\right)_{2} \mathrm{SO}_{4}$ under different moisture regimes. Soil, Biology and Biochemistry. 17: 747-756.

Vance, E.D., Brookes, P.C. and Jenkinson, D.S. (1987). An extraction method for measuring soil microbial biomass C. Soil, Biology and Biochemistry. 19: 703-807.

Walkley, A. and Black, I.A. (1934). An examination of Degtjareff method for determining soil organic matter and a proposed modification of the chromic acid titration method. Soil Science. 37: 29-37.

Wong, M.T.F., Van Der Kruijs, A.C.B. M. and Juo, A.S.R. (1992). Leaching loss of calcium, magnesium, potassium and nitrate derived from soil, lime and fertilisers as influenced by urea applied to undisturbed lysimeters in South-East Nigeria. Nutrient Cycling and Agroecosystem. 31: 281-289. 